\title{
Flow dynamics and iceberg calving rates of Devon Ice Cap, Nunavut, Canada
}

\author{
David O. BURGESS, ${ }^{1}$ Martin J. SHARP, ${ }^{1}$ Douglas W.F. MAIR, ${ }^{2}$ \\ Julian A. DOWDESWELL, ${ }^{3}$ Toby J. BENHAM ${ }^{3}$ \\ ${ }^{1}$ Department of Earth and Atmospheric Sciences, University of Alberta, Edmonton, Alberta T6G 2E3, Canada, \\ E-mail: dob@ualberta.ca \\ ${ }^{2}$ Department of Geography, University of Aberdeen, Elphinstone Road, Aberdeen AB24 $3 U F$, UK \\ ${ }^{3}$ Scott Polar Research Institute, University of Cambridge, Lensfield Road, Cambridge CB2 1ER, UK
}

\begin{abstract}
The surface velocity field of Devon Ice Cap, Nunavut, Canada, was mapped using interferometric synthetic aperture radar (InSAR). Ascending European Remote-sensing Satellite 1 and 2 (ERS-1/-2) tandem mode data were used for the western and southeast sectors, and 3 day repeat pass ERS-1 imagery for the northeast sector. Speckle-tracking procedures were used with RADARSAT 1 imagery to obtain surface velocities over the terminus of Belcher Glacier (a major calving front) where decorrelation between ERS data occurred. The InSAR data highlight a significant contrast in ice-flow dynamics between the east and west sides of the ice cap. Ice movement west of the main north-south divide is dominated by relatively uniform 'sheet' flow, but three fast-flowing outlet glaciers that extend 14-23 km beyond the ice-cap margin also drain this region. Several outlet glaciers that extend up to $60 \mathrm{~km}$ inland from the eastern margin drain the eastern side of the ice cap. The dominant ice-flow regimes were classified based on the relationship between the driving stress (averaged over a length scale of ten ice thicknesses) and the ratio of surface velocity to ice thickness. The mapped distribution of flow regimes appears to depict the spatial extent of basal sliding across the ice cap. This is supported by a close relationship between the occurrence of flow stripes on the ice surface and flow regimes where basal sliding was found to be an important component of the glacier motion. Iceberg calving rates were computed using measured surface velocities and ice thicknesses derived from airborne radio-echo sounding. The volume of ice calved between 1960 and 1999 was estimated to be $20.5 \pm 4.7 \mathrm{~km}^{3}$ (or $0.57 \mathrm{~km}^{3} \mathrm{a}^{-1}$ ). Approximately $89 \%$ of this loss occurred along the eastern margin. The largest single source is Belcher Glacier, which accounts for $\sim 50 \%$ of the total amount of ice calved.
\end{abstract}

\section{INTRODUCTION}

Most of the outlet glaciers that drain the interior regions of Devon Ice Cap, Nunavut, Canada, terminate in tidewater, making them potentially sensitive to changes in both climate and sea level. Iceberg calving from the termini of these glaciers has not previously been quantified, but may constitute a significant mode of mass loss from the ice cap. The rate of calving may be sensitive to changes in the flow dynamics of the glaciers and to changes in terminus position related to instabilities of the grounding line. Knowledge of the velocity structure of the ice cap is essential for identifying the major pathways by which ice is removed from the ice cap, and for estimating the rate of mass loss by iceberg calving and its relative contribution to overall changes in the mass of the ice cap. A recent study by Burgess and Sharp (2004) estimated that Devon Ice Cap has decreased in volume by $\sim 67 \mathrm{~km}^{3}$ between 1960 and 1999 . Mair and others (2004) suggest that surface melting may account for $60-90 \%$ of this loss, indicating that iceberg calving may account for up to $40 \%\left(27 \mathrm{~km}^{3}\right)$ of the total mass loss over this time interval.

In this study, surface velocities were derived for almost the entire Devon Ice Cap using interferometric synthetic aperture radar (InSAR). The pattern of surface velocities in the look direction of the satellite was analyzed to identify the dominant ice-flow regimes and the spatial relationships between slow- and fast-flowing sectors of the ice cap. Downslope surface velocities were projected from look direction velocities in order to quantify the flow rates of all major glaciers on the ice cap. Ice-thickness data acquired using airborne radio-echo sounding (Dowdeswell and others, 2004) were used in conjunction with surface velocity values to calculate calving fluxes at the terminus of $94 \%$ of all tidewater glaciers draining the ice cap. The velocity and ice-thickness data were also used to investigate the nature of the transition zones between slow and fast ice flow, and the mechanisms of ice flow along the major glaciers that drain the interior regions of the ice cap.

\section{STUDY AREA}

Devon Ice Cap occupies approximately $14000 \mathrm{~km}^{2}$ of the eastern part of Devon Island, Nunavut, in the Canadian High Arctic (Fig. 1). Landsat 7 Enhanced Thematic Mapper Plus (ETM+) imagery acquired in 1999 suggests that iceflow patterns are strongly influenced by the form of the underlying bedrock surface, and that they differ significantly between the east and west sides of the ice cap. West of the central north-south divide, the ice cap rests on a relatively flat plateau, and flows westwards as a single broad lobe $(\sim 82 \mathrm{~km}$ long $)$ that terminates on land between 400 and $600 \mathrm{~m}$ a.s.l. This region is also drained by two outlet glaciers that flow south into Croker Bay and by Sverdrup Glacier which flows north into Jones Sound (Fig. 2). These glaciers all extend $>14 \mathrm{~km}$ beyond the main ice-cap margin. East of the central divide, the topography 


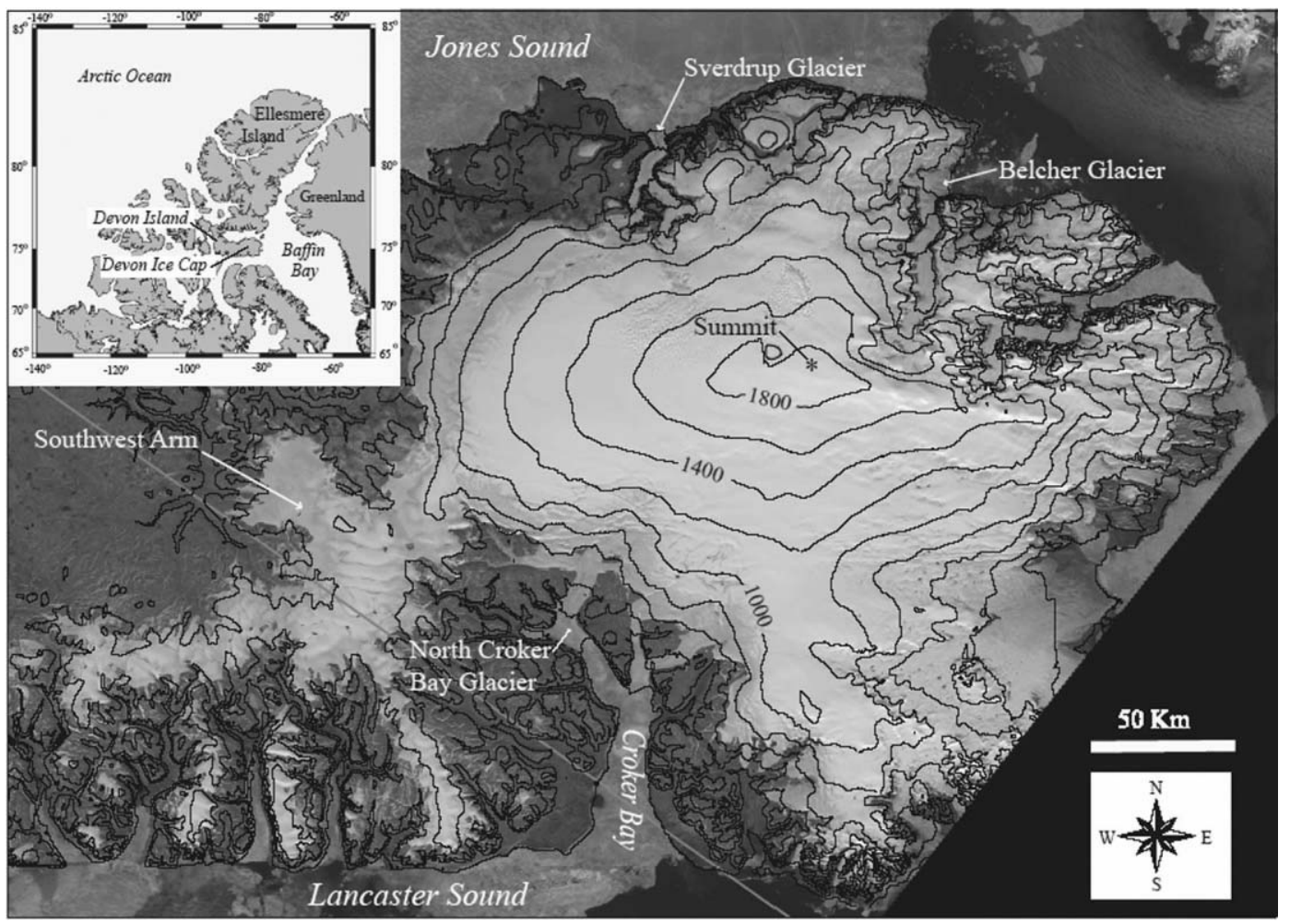

Fig. 1. 1999 Landsat 7 ETM+ ortho-mosaic of Devon Ice Cap. Inset shows the location of Devon Ice Cap in the Canadan Arctic Archipelago.

is primarily mountainous. Large outlet glaciers that extend up to $41 \mathrm{~km}$ inland from the coast drain the northeast sector. The east-central region is dissected by a series of outlet glaciers that extend up to $60 \mathrm{~km}$ inland from the ice-cap margin. Most of these outlet glaciers terminate in tidewater, and they comprise $89 \%$ of the $73 \mathrm{~km}$ of the icecap margin that reaches the sea (Dowdeswell and others, 2004). Flow stripes are characteristic surface features along these glaciers (see Fig. 3), indicating that ice motion is likely due to sliding at the glacier bed (Gudmundsson and others, 1998, 2003). Margin-parallel layering and surface-parallel meltstreams are surface features common to the remaining areas of the ice cap below $\sim 1000 \mathrm{~m}$ a.s.l.

\section{INTERFEROMETRIC MEASUREMENTS}

Surface velocity fields across Devon Ice Cap were derived from InSAR which measures topography and displacement of the Earth's surface as a result of the interference pattern created between a coherent pair of radar images acquired from successive satellite passes along the same orbital path
(Massonnet and Feigl, 1998). In order to isolate the component of surface motion in the interferogram, the effects of topography must be removed either by subtracting an independent digital elevation model (DEM) from the InSAR pair (Joughin and others, 1996) or through double-differencing with a second coherent InSAR pair (Gabriel and others, 1989). In this study, double-differencing was performed with two radar pairs acquired over the southeast region of the ice cap during the European Remote-sensing Satellite 1 and 2 (ERS-1/-2) tandem mode mission in 1996 (see Table 1 for orbital pairs and Fig. 2 for the footprint of the radar images). Topography was removed from the interferograms over the western half and the northeast region (where only single radar pairs were available) using the Canadian digital elevation dataset (CDED) as the external DEM. The 'motion-only' interferograms were unwrapped and converted to absolute values by referencing bedrock features identifiable in the radar imagery to zero velocity (Zebker and others, 1994). The three 'motion-only' interferograms were then manually mosaicked to produce line-of-sight velocity fields ( $\left.V_{\mathrm{LOS}}\right)$ over $98 \%$ of the ice-cap surface (Fig. 2). Line-of-sight

Table 1. Orbit numbers and dates of radar imagery used for mapping surface velocities of the Devon Ice Cap

\begin{tabular}{|c|c|c|c|c|}
\hline Ice-cap region & RADARSAT orbit & ERS orbit & ERS image dates & $\begin{array}{l}\text { Perpendic } \\
\mathrm{m}\end{array}$ \\
\hline Southeast & - & $24397 / 4724,24898 / 5225$ & 15-16 Mar., 19-20 Apr. 1996 & 187,64 \\
\hline West & - & $24894 / 5311$ & 25-26 Apr. 1996 & -1 \\
\hline Northeast & - & $2924 / 2967$ & 6/9 Feb. 1992 & 60 \\
\hline Belcher terminus & $25810 / 26153$ & - & 14 Oct-7 Nov. 2000 & - \\
\hline Belcher terminus & $26345 / 26688$ & - & 20 Nov.-14 Dec. 2000 & - \\
\hline
\end{tabular}




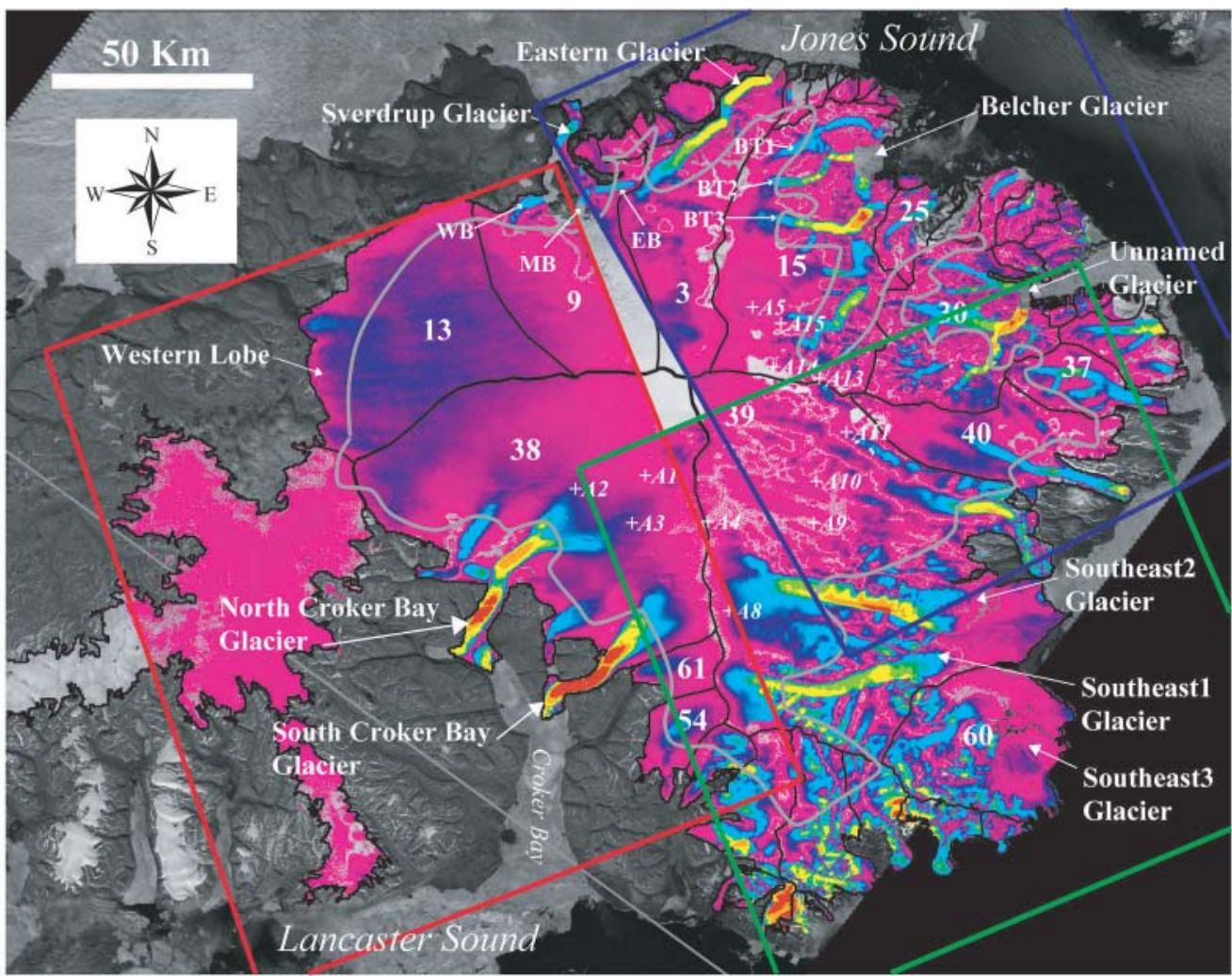

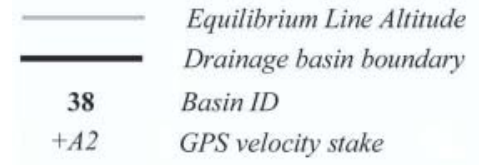

Satellite look direction ( $54^{\circ}$

$\begin{array}{ll}\text { WB } & \text { West Branch } \\ \text { MB } & \text { Main Branch } \\ \text { EB } & \text { East Branch } \\ \text { BT1 } & \text { Belcher Tributary1 } \\ \text { BT2 } & \text { Belcher Tributary2 } \\ \text { BT3 } & \text { Belcher Tributary3 }\end{array}$

Look Direction Velocities $\left(\mathrm{m} \mathrm{a}^{-1}\right)$

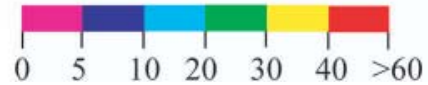

Fig. 2. Look direction surface velocities overlaid onto a 1999 Landsat 7 ETM+ satellite ortho-mosaic of Devon Ice Cap. Accelerated glacier flow is identified by the closely spaced coloured fringes which are evident along the entire length of most of the major outlet glaciers. Red, green and blue boxes outline the footprints for the west, southeast and northeast ERS radar image pairs respectively. Orbital numbers are listed in Table 1. The ELA used here is situated at $\sim 800 \mathrm{~m}$ a.s.l. throughout the southeast, $\sim 950 \mathrm{~m}$ a.s.l. throughout the northwest and $875 \mathrm{~m}$ a.s.l. throughout the southwest and northeast regions of the ice cap (Koerner, 1970).

velocities were projected to true downslope velocities $\left(V_{\mathrm{DS}}\right)$ based on the satellite ice surface geometry (Vachon and others, 1996; Cumming and Zhang, 2000) according to the formula:

$$
V_{\mathrm{DS}}=\frac{V_{\mathrm{LOS}}}{(\cos \alpha \sin v \sin \theta)+(\sin \alpha \cos \theta)},
$$

where $\alpha$ is the slope of the ice-cap surface, $v$ is the angle between the look direction of the satellite and the direction of ice flow, and $\theta$ is the incidence angle of the radar beam (33 for the ERS satellites). Throughout the interior regions of the ice cap, ice was assumed to flow in the direction of maximum slope of ice-cap surface. Surface slopes were computed from the CDED that was smoothed at a horizontal scale equivalent to $\sim 6$ times the local ice thickness. The direction of ice flow over outlet glaciers was mapped from the orientation of flow stripes visible in the Landsat 7 ETM+ imagery. Projecting line-of-sight velocities to downslope velocities produces unreliable results over regions where ice flow is nearly perpendicular to the look direction of the satellite (Unwin, 1998). Therefore, since InSAR from only a single look direction was available, true surface velocities could be computed for only $\sim 75 \%$ of the ice-cap surface.

\section{Error estimates for InSAR measurements}

The main source of velocity error $\left(V_{\text {error }}\right)$ associated with the measurements of downslope surface displacement derives from projecting the line-of-sight velocities from a single look angle. Throughout the interior regions where ice velocity is generally $<20 \mathrm{~m} \mathrm{a}^{-1}, V_{\text {error }}$ was quantified by comparing the projected InSAR data with point velocity values from repeat differential global positioning system (DGPS) measured in the field. The positions of 13 velocity stakes deployed above the equilibrium-line altitude (ELA; Fig. 2) were measured during May 2000 using Leica Geosystems Series 500 GPS dual frequency antennae. GPS tracking data were collected for 3-4 hours at each site. The data were post-processed using the GIPSY-OASIS II software package (Webb and Zumberge, 1995), which includes models and estimation algorithms, developed by NASA's Jet Propulsion Laboratory (JPL), that account for orbit, Earth orientation, clock biases and a range of other geodetic and astronomic parameters. The $1 \sigma$ uncertainty in horizontal positioning was $<0.02 \mathrm{~m}$ (personal communication from J.F. Zumberge, 2004). Repeat measurements were made at each stake in April 2001. Slight measurement errors may have been incurred in the repositioning of antennae on the stakes and from 


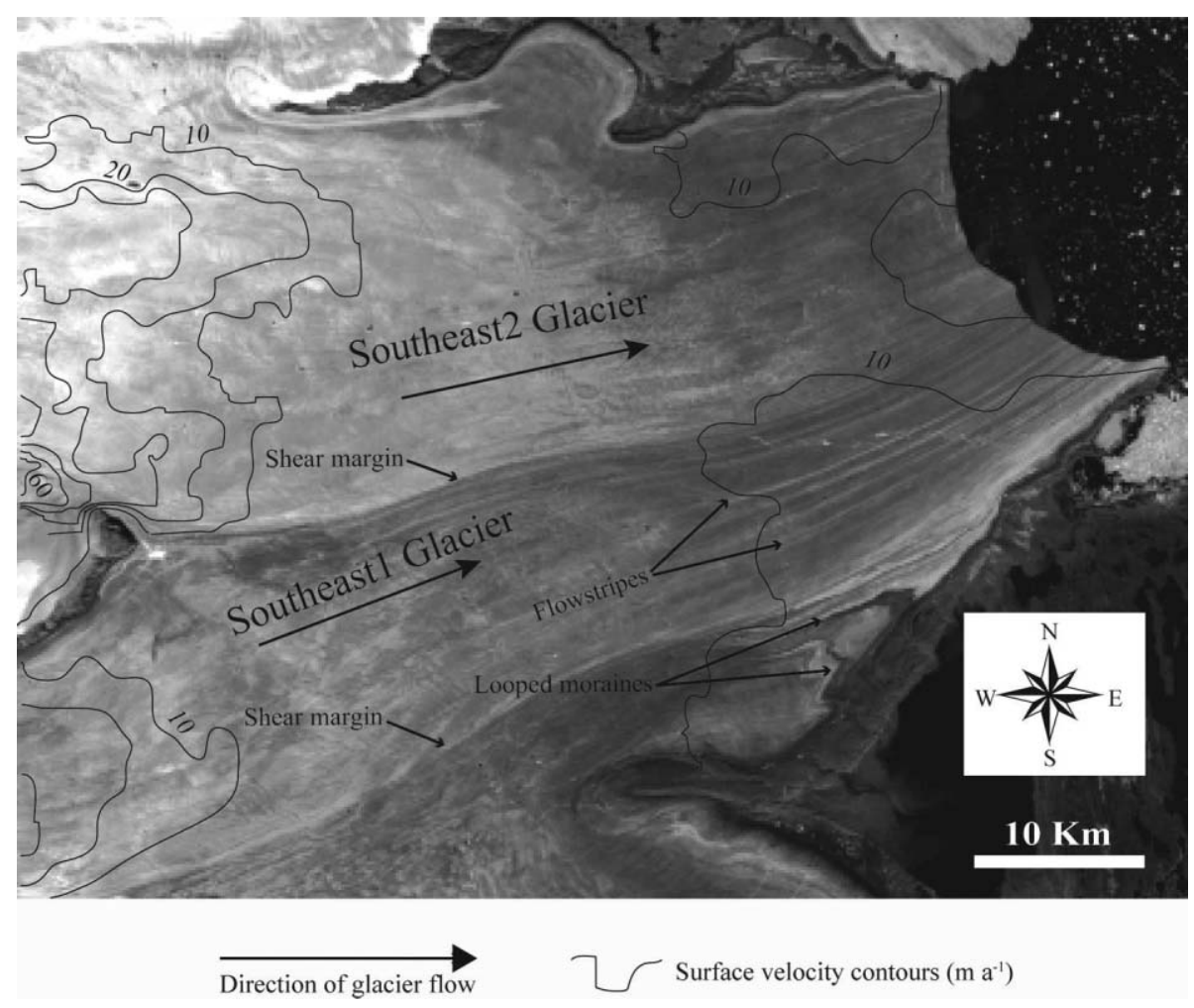

Fig. 3. A subset of a 2000 Landsat 7 ETM+ image mosaic highlighting surface features indicative of fast glacier flow throughout the terminus region of the Southeast 1 and Southeast 2 glaciers.

wind-induced movement during measurement periods. We estimate the error in the annual surface displacement measurements to be $<0.05 \mathrm{~m}$. Measured annual surface displacements ranged from $2.33 \mathrm{~m}$, near the saddle of the southern half of the north-south ice divide, to $12.24 \mathrm{~m}$ just above the equilibrium line in the southeastern sector (A8 and A9 respectively in Fig. 2). The average discrepancy between the velocity stake data and the associated InSAR pixel data agreed to within an average of $\pm 2.54 \mathrm{ma}^{-1}$, indicating a conservative $V_{\text {error }}$ of $\pm 3 \mathrm{ma}^{-1}$ throughout the interior regions of the ice cap. $V_{\text {error }}$ over ice moving $>20 \mathrm{~m} \mathrm{a}^{-1}$ (where DGPS velocity measurements were not performed) was found to be a function of the accuracy with which the direction of ice flow was measured. The direction of ice flow over these regions was determined from the visual inspection of flow stripes in the Landsat 7 imagery and was estimated to be accurate to within $\pm 2^{\circ}$ in azimuth. This error translated into an accuracy of $2-10 \%$ of the projected surface velocity values, depending on the angle between the direction of ice flow and the look angle of the satellite. Significant variability in seasonal velocity measured over several High Arctic glaciers (Cress and Wyness, 1961; Iken, 1972; Bingham and others, 2003; Copland and others, 2003a) suggests that additional error may be introduced when extrapolating InSAR-derived velocity measurements to annual values. Summer velocities up to $100 \%$ higher than winter velocities were recorded at certain low-elevation velocity stakes by Copland and Sharp (2001) on John Evans Glacier, Nunavut. Such variability would not be detected in the short-term (1-3 day) InSAR velocity measurements. Although the effects of seasonal variability cannot be quantified due to a lack of summer velocity measurements over the ice cap, it is likely that the areas affected are restricted to the main outlet glaciers. Since the radar imagery used in this study was acquired in the winter and spring months (before the onset of melt), velocities derived from these data likely represent minimum annual values.

\section{SPECKLE-TRACKING MEASUREMENTS}

Intense crevassing and relatively high velocities at the termini of Eastern, Belcher and Unnamed Glaciers caused decorrelation between the ERS 3 day repeat pass image pairs over these regions. The technique of speckle tracking (Gray and others, 2001; Joughin, 2002) was therefore used to measure surface velocities over the terminus of Belcher Glacier. Speckle tracking measures movement of the surface of the Earth between two coherent radar images acquired from successive orbital cycles (Gray and others, 2001). Coherence is based on the backscatter properties of each image, which allow the pairs to be co-registered to within a fraction of a pixel. In this study, pixels were resampled to $250 \mathrm{~m}$ resolution. Displacement rates and directions are measured by matching the speckle pattern of a roving chip (several pixels in size) to a reference image. Unfortunately, poor coherence between the RADARSAT 1 pairs precluded the application of this technique to other areas of the ice cap. Ice velocities of $180-300 \mathrm{~m} \mathrm{a}^{-1}$ were measured throughout the terminal reaches of Belcher Glacier. Velocities of up to $21 \mathrm{~m} \mathrm{a}^{-1}$ were, however, measured over adjacent bedrock outcrops (where velocity should be $0 \mathrm{~m} \mathrm{a}^{-1}$ ), indicating that the error of the velocity estimates is up to $10 \%$ of the measured value.

\section{ICEBERG CALVING RATE}

The volume of ice calved was quantified for $94 \%$ of that part of the perimeter of the ice cap that terminates at sea level. 
Total discharge was calculated as:

$$
Q_{\text {Total }}=Q_{\text {flux }}+Q_{\text {v_loss, }}
$$

where $Q_{\text {flux }}$ is the volume of ice flux discharged at the tidewater termini between 1960 and 1999, and $Q_{v_{-} \text {loss }}$ is the volume loss due to the observed change of terminus position over that interval (Burgess and Sharp, 2004).

Although the predominant ice-flow regimes at the location of the flux gates for which $Q_{\text {flux }}$ was determined are known (derived in a later section), the exact ratio of sliding to ice deformation at each gate is not known. A range of estimates of $Q_{\text {flux }}$ was therefore made, based on different assumptions regarding the contribution of internal deformation to overall glacier motion. The maximum estimate was based on the assumption that glacier flow was entirely by basal sliding or bed deformation $\left(V_{\text {sliding }}=V_{\mathrm{DS}}\right)$. The minimum estimate assumed that internal deformation also contributed to glacier flow, and that the depth-averaged velocity was equal to $80 \%$ of the measured downslope surface velocity $\left(V_{\text {depth_avg }}=V_{\mathrm{DS}} \times 0.8\right.$; Paterson, 1994). The occurrence of flow stripes on all major glaciers, however, suggests that basal motion is likely more important to glacier flow than internal deformation, indicating that the upper velocity estimate is probably closer to the actual value.

Flux gates were located as close as possible to the termini of all tidewater glaciers. However, flux gates of Eastern and Unnamed Glaciers had to be positioned $3 \mathrm{~km}$ up-glacier from their termini due to a lack of surface velocity data for regions further downstream. Also, ice flux from $6 \%$ of that part of the ice-cap perimeter that terminates at sea level could not be derived due to an absence of surface velocity data. The glaciers concerned originate from relatively small basins isolated from the main ice cap, however, and probably do not contribute significantly to the volume of ice discharged from the ice cap.

Another important source of error associated with the iceberg calving flux measurements (besides $V_{\text {error }}$ ) is inaccuracies in the ice-thickness data $\left(h_{\text {error }}\right)$. Point measurements of ice thickness were obtained in 2000 (Dowdeswell and others, 2004) along transects flown 5-10 km apart in north-south and east-west directions across the main part of the ice cap, and up the centre lines of most of the main outlet glaciers. The data were then interpolated across the entire ice cap using an inverse distance-weighted surfacing algorithm constrained by exposed bedrock visible in the 1999 Landsat ETM+ imagery in order to properly constrain channelized flow (Dowdeswell and others, 2004). The spatial resolution of the resultant gridcells was $1 \mathrm{~km}$, with an estimated error in ice thickness of $\pm 10 \mathrm{~m}$. Errors associated with glacier width $(W)$ at the location of the flux gate were considered insignificant.

Other sources of error associated with extrapolating calving flux estimates over the period 1960-99 are introduced by the variability in velocity of these glaciers on seasonal and/or long-term time-scales. As mentioned above, velocities near the glacier termini may fluctuate on a seasonal time-scale, indicating that the spring InSAR data used to derive velocity estimates in this study likely underestimate the actual annual velocities, and hence rates of calving flux. Since significant summer melting generally only extends from early July to early August (Alt, 1978), the resulting fluctuations in flow rate should not affect the annual velocity measurements by more than $\sim 10 \%$. It is difficult to estimate the long-term variability in glacier flow, due to the lack of velocity data across most of the ice cap over the past 40 years. However, a point velocity of $36 \mathrm{~m} \mathrm{a}^{-1}$ measured on Sverdrup Glacier by Cress and Wyness (1961) agrees to within $5 \mathrm{ma}^{-1}$ with the 1996 InSAR measured velocity, suggesting a reasonably consistent rate of flow at this location since 1960. On the other hand, evidence of fast glacier flow (see Fig. 3) near the termini of the Southeast 1 and Southeast 2 glaciers indicates that the velocity throughout this region (which is currently $<15 \mathrm{~m} \mathrm{a}^{-1}$ ) has decreased significantly since the formation of these surface features. If this apparent reduction in velocity has occurred since 1960, the extrapolated calving flux derived from the InSAR data would be an underestimate of the 40 year average across this calving front.

Upper and lower estimates of flux $\left(Q_{\max }\right.$ and $Q_{\min }$ respectively) at each gate were calculated from the formulae:

$$
\begin{gathered}
Q_{\max }=V T_{\max } W \\
Q_{\min }=V T_{\min } W,
\end{gathered}
$$

where

$$
V T_{\max }=\left(V_{\text {sliding }}+V_{\text {error }}\right)\left(h+h_{\text {error }}\right)
$$

and

$$
V T_{\min }=\left(V_{\text {depth_avg }}-V_{\text {error }}\right)\left(h-h_{\text {error }}\right) .
$$

$V T_{\max }$ and $V T_{\min }$ represent average values across the flux gates which were then multiplied by the flux gate width. This technique of averaging pixel values along the flux gate, as opposed to a summation of the pixel values, was chosen to avoid including extra pixels in the calculation which can occur when representing irregular or diagonal lines in a gridded format.

The value of $Q_{v_{-} \text {loss }}$ was calculated as the product of the 1960-99 area change and the average of all gridded icethickness values across the tidewater terminus of each outlet glacier. Area changes were determined as the difference between the 1960 and 1999 outlines of the ice-cap margin (Burgess and Sharp, 2004). The estimated accuracy of volume-change measurements at the glacier termini was derived by assuming a $\pm 15 \mathrm{~m}$ digitizing error around the perimeter of the area of change and a $\pm 10 \mathrm{~m}$ error in the measured ice thickness. Due to the absence of bathymetry data beyond the tidewater termini, volume changes were derived assuming that the thickness of ice throughout the area of change is consistent with ice thickness along the current ice margin.

\section{RESULTS}

\section{Flow pattern of Devon Ice Cap}

The line-of-sight velocity map reveals a significant difference in the pattern of ice flow between the eastern and western sectors of Devon Ice Cap (Fig. 2). In the western half of the ice cap, ice movement occurs predominantly by slow 'sheet' flow $\left(<\sim 15 \mathrm{~m} \mathrm{a}^{-1}\right)$, although several areas of more rapid flow occur along the southwest margin. The largest of these areas occurs up-glacier of North Croker Bay Glacier, where more rapid flow penetrates up to $30 \mathrm{~km}$ inland from the icecap margin. Flow associated with South Croker Bay Glacier penetrates up to $20 \mathrm{~km}$ inland of the ice-cap margin. The Croker Bay glaciers terminate in Lancaster Sound, and their velocities reach maxima of $\sim 210$ and $\sim 240 \mathrm{~m} \mathrm{a}^{-1}$ for the 
north and south glaciers respectively. A third region of more rapid flow is associated with Sverdrup Glacier which flows north into Jones Sound. Unfortunately, a lack of velocity data precludes analysis of the inland extent of enhanced glacier flow in this region. However, R.M. Koerner (personal communication, 2004) indicated that the inland extent of fast glacier flow associated with Sverdrup Glacier is defined by the concave-up form of the ice-cap surface which extends $\sim 5 \mathrm{~km}$ inland of where the glacier enters the main valley. Sverdrup Glacier draws ice from both its main tributary (main branch; Fig. 2), and an eastern arm (east branch; Fig. 2), the up-glacier extension of which is restricted by the head of Eastern Glacier. Enhanced ice flow at the head of a third flow feature to the west of the main tributary (west branch; Fig. 2) is limited as it terminates approximately $14 \mathrm{~km}$ down-glacier of its head and does not contribute to the flow of Sverdrup Glacier.

Ice drainage from the northeast sector of the ice cap occurs primarily via large outlet glaciers that flow through mountain valleys to reach sea level. Most of the glaciers in this region originate at valley heads that restrict the inland extension of fast ice flow. Exceptions to this are Eastern Glacier (basin 3) and three tributary glaciers to the Belcher (Belcher tributaries 1-3; Fig. 2), all of which draw from the slower-flowing ice of the interior region. Belcher Glacier itself originates along the north slope of the main east-west ice divide. In the upper reaches of this glacier, velocity increases to $\sim 75 \mathrm{ma}^{-1}$ upstream of the confluence with Belcher tributary $1 \sim 15 \mathrm{~km}$ up-glacier from the terminus. Velocities increase to $\sim 120 \mathrm{~m} \mathrm{a}^{-1}$ at this confluence, reaching maximum values of $\sim 290 \mathrm{~m} \mathrm{a}^{-1}$ at the glacier terminus. Belcher tributaries 2 and 3 merge with the main glacier at the terminus, forming the widest 'fast-flowing' calving front on the ice cap.

Velocities of Eastern Glacier increase over approximately $30 \mathrm{~km}$ from the slow-moving interior regions to reach a maximum of $\sim 120 \mathrm{~m} \mathrm{a}^{-1}, 10 \mathrm{~km}$ up-glacier from the terminus. Although velocities at the terminus of Eastern Glacier could not be measured, intense crevassing suggests that the speed of this glacier increases as it approaches marine waters. The remaining ice in the northeast sector is drained through a series of tidewater glaciers that range in maximum speed from 30 to $100 \mathrm{~m} \mathrm{a}^{-1}$. These glaciers drain relatively small basins $\left(<\sim 15 \mathrm{~km}^{2}\right)$ that are separate from the main ice-cap accumulation area.

'Fast' flow along Southeast 1 and Southeast 2 glaciers extends farther into the accumulation zone than any other flow feature across the ice cap (Fig. 2). The ice divide at the head of Southeast 1 has a convex up-glacier form, suggesting that this outlet glacier may be extending headwards into the less active basin to the west (basin 54). Both glaciers converge $40 \mathrm{~km}$ down-glacier from the head, resulting in a near-stagnant region $\left(<10 \mathrm{~m} \mathrm{a}^{-1}\right)$ approximately $250 \mathrm{~km}^{2}$ in area that terminates along an $8 \mathrm{~km}$ ice front in Hyde Inlet (Fig. 2). Despite low velocities throughout this region, flow stripes visible on the surface of Southeast 1 Glacier suggest that this feature was once flowing faster than at present (Fig. 3). Sharp shear zones along both margins and folded moraines near the terminus are indicators that this glacier may indeed have surged in the past (Dowdeswell and Williams, 1997; Copland and others, 2003b).

Ice from the southern slopes of the Cunningham Mountains drains through a series of steep valley glaciers towards Lancaster Sound, most of which terminate on land.
Included in this group is a possible surge-type glacier identified by Copland and others (2003b). Measured velocities on this glacier reach a maximum of $\sim 150 \mathrm{~m} \mathrm{a}^{-1}$, but the surface morphology of the glacier suggests that, if it is indeed a surge-type glacier, it is currently in the quiescent phase of a surge cycle.

\section{Glacier flow regimes}

Four major flow regimes were identified based on the relationship between the ratio of surface velocity to ice thickness $(v / h)$ and the driving stress $\left(\tau_{\mathrm{d}}\right)$ along four flowlines across the ice cap (Fig. 6 below). When the ice flow is solely due to ice deformation, the parameter $(v / h)$ represents the mean shear strain rate in a vertical profile through the ice. When basal motion is important, this parameter no longer represents the shear strain rate in the ice, but the inverse of the ratio of $v / h$ to $\tau_{\mathrm{d}}$ has units of Pas and is therefore a measure of the 'effective viscosity' of the glacier system.

$\tau_{\mathrm{d}}$ was derived from:

$$
\tau_{\mathrm{d}}=\rho_{\mathrm{i}} g h \sin \alpha,
$$

where $\rho_{\mathrm{i}}$ is the density of ice $\left(910 \mathrm{~kg} \mathrm{~m}^{-3}\right)$ and $g$ is the acceleration due to gravity $\left(9.81 \mathrm{~m} \mathrm{~s}^{-2}\right)$. The effects of local variations in surface slope due to longitudinal stress gradients in the ice were removed by averaging surface slope values over distances equivalent to $\sim 10$ times the ice thickness.

Flow regime 1 is distinguished by values of $v / h<0.075 \mathrm{a}^{-1}$ and a high positive correlation with $\tau_{\mathrm{d}}\left(r^{2}>0.85\right)$, though the sensitivity of $v / h$ to changes in $\tau_{\mathrm{d}}$ is low (Fig. 4a-d). This behaviour suggests that the ice is frozen to the bed, and glacier movement is by internal deformation alone (Budd and Smith, 1981; Cooper and others, 1982). Within this flow regime, however, the ratio of $v / h$ to $\tau_{\mathrm{d}}$ may increase downstream (Fig. $4 a-c$ ). This is probably a reflection of softening of the ice as it warms up with increasing distance of transport.

Flow regime 1 is characteristic of the upper reaches leading into major outlet glaciers (Fig. $5 \mathrm{a}-\mathrm{C}$ ) and of the whole western lobe (Fig. $5 \mathrm{~d}$ ). In these regions, glaciers have convex upward surface profiles (Fig. 6a-d), and flow is not constrained laterally by bedrock topography. Flow regime 1 is also observed in the terminal reaches of the Southeast 1 Glacier flowline where the velocity, and hence $v / h$, is low (Figs 3 and 6c). In this region, $v / h$ decreases as $\tau_{d}$ rises, suggesting increased flow resistance and 'effective viscosity' towards the glacier terminus. This may be indicative of a frozen bed at the glacier margin.

The relationship between $v / h$ and $\tau_{d}$ changes significantly at $v / h \sim 0.075 \mathrm{a}^{-1}$ (flow regime 2; Fig. $4 \mathrm{a}-\mathrm{C}$ ). In this flow regime, the ratio of $v / h$ to $\tau_{\mathrm{d}}$ is generally higher, the relationship between the two variables is more sensitive, and the sign of the relationship may be opposite to that observed in flow regime 1 (Fig. $4 \mathrm{~b}$ and c). This is not, however, always the case (Fig. 4a). The ensemble of changes observed suggests a down-flow reduction in 'effective viscosity' and flow resistance, and a contribution of basal motion to the surface velocity. The beginning of flow regime 2 coincides with convergent flow at the head of the major outlet glaciers (Fig. 5a and c) and the appearance of flow stripes on the ice surface (Fig. 5a-C). Gudmundsson and others (1998) argued that flow stripes form only where the velocity at the bed is large relative to shearing through the ice thickness, supporting the argument that basal motion must be 

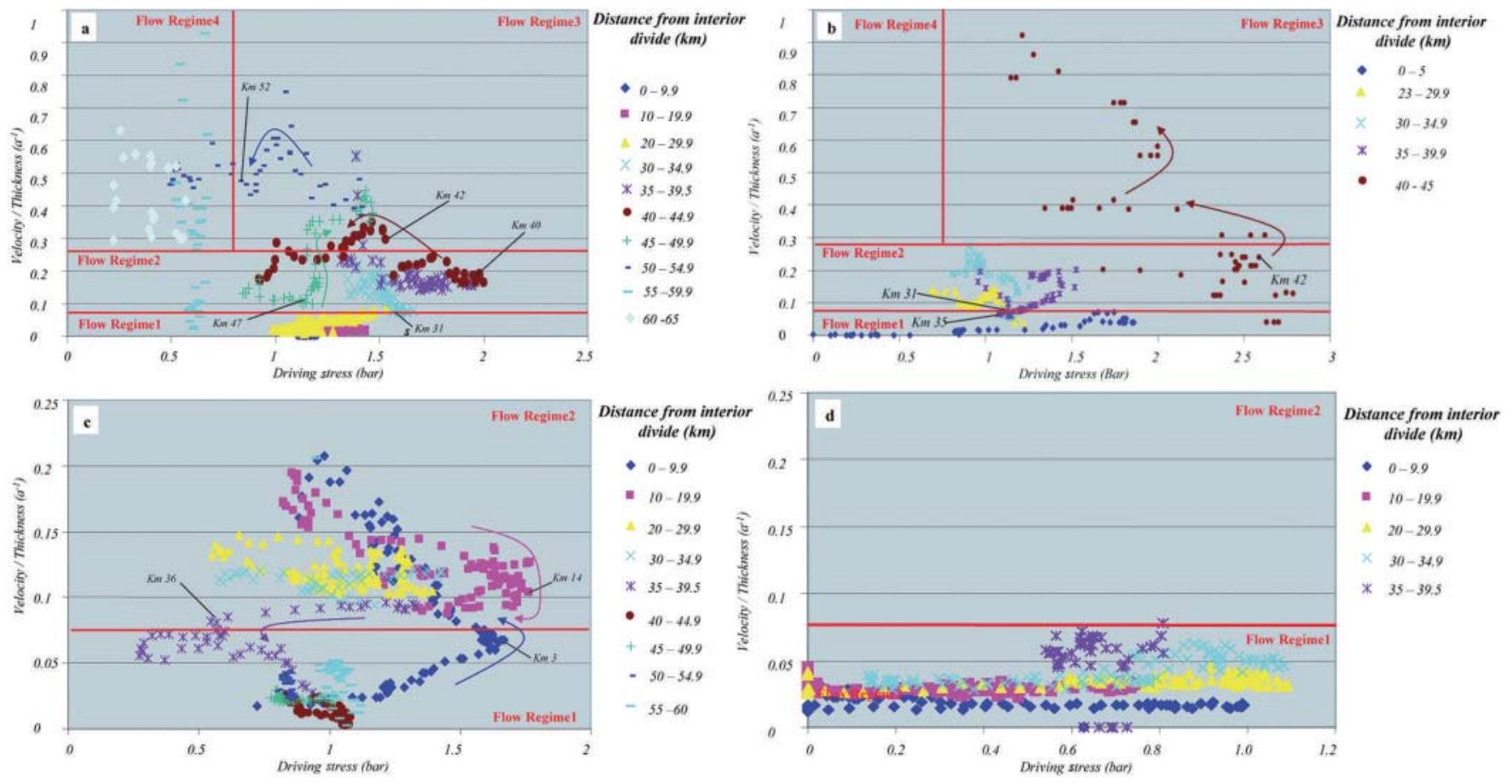

Fig. 4. The predominant modes of glacier flow across Devon Ice Cap are identified based on the relationship between mean shear strain rate $(v / h)$ and driving stress $\left(\tau_{d}\right)$ along profiles of (a) North Croker Bay Glacier, (b) Belcher Glacier, (c) Southeast 1 Glacier and (d) the western lobe. Threshold values (red lines) separate each distinct ice-flow regime based on changes in the relative slope of the clusters in each feature space. Coloured arrows in $(\mathrm{a}-\mathrm{c})$ indicate the down-glacier direction of ice flow.

significant in regions with this flow regime. Flow regime 2 commences $\sim 5 \mathrm{~km}$ up-glacier from steps in the bedrock topography along North Croker Bay and Southeast 1 Glaciers (Fig. 6a and c). These locations also coincide with the transformation to a concave-up surface profile (Fig. 6a-c) from the convex-up profile which is characteristic of flow regime 1 . Rapid acceleration of $V_{\mathrm{DS}}$ and ice thinning at the cusp of the bedrock steps (Fig. $6 \mathrm{a}$ and c) indicate that the onset of basal sliding is controlled primarily by the subglacial topography at these locations (Mclntyre, 1985).

Ice-flow regime 3 appears to be defined by threshold values of $v / h>\sim 0.28 \mathrm{a}^{-1}$ and $\tau_{\mathrm{d}}>\sim 0.075 \mathrm{MPa}$ (Fig. $4 \mathrm{a}$ and b). In this region, $v / h$ is inversely related to $\tau_{d}$, and the slope of the relationship between the two variables is steeper than in flow regime 2 . The ratio of $v / h$ to $\tau_{\mathrm{d}}$ is higher again than in flow regime 2 , implying a further reduction in viscosity and probably an increase in the relative contribution of basal motion to the surface velocity. Regions of flow regime 3 occur throughout the mid- to lower reaches of the major glaciers where flow stripes are well developed on the ice surface. Along the North Croker Bay Glacier flowline, flow regime 3 begins where the glacier enters the bedrock valley at $\mathrm{km} 48$ (Fig. 5a) and $V_{\mathrm{DS}}$ increases rapidly $\left(60-170 \mathrm{~m} \mathrm{a}^{-1}\right.$ over a $1 \mathrm{~km}$ distance). A rapid increase of $V_{\mathrm{DS}}$ (and hence $v / h$ ) marks the beginning of flow regime 3 at $\mathrm{km} 42$ along the Belcher Glacier flowline (Fig. 5b). In contrast to North Croker Bay Glacier, however, the flow of ice within this region is driven mainly by large values of $\tau_{d}$ that occur over steeply sloping (and rough) bed topography that descends to $\sim 300 \mathrm{~m}$ below sea level within $2 \mathrm{~km}$ of the glacier terminus. In both situations, intense crevassing at the onset of flow regime 3 suggests that an increase in the rate of ice deformation occurs at the transition from flow regime 2 to flow regime 3 . In addition, meltwater channels terminating at these crevasse fields (visible in the 1960s aerial photography) indicate that surface run-off may penetrate to the glacier bed via the crevasses and potentially enhance flow rates throughout this zone during the summer months. A fourth regime, flow regime 4 , is defined by threshold values of $v / h>0.28 \mathrm{a}^{-1}$ and $\tau_{\mathrm{d}}<0.075 \mathrm{MPa}$ (Fig. 4a). In this region, the wide range of values of $v / h$ for consistently low values of $\tau_{\mathrm{d}}$ is indicative of low friction at the glacier bed. This may suggest that deformation of subglacial sediments contributes to basal motion, which remains a major component of the surface velocity of the glacier. Flow regime 4 is characteristic of the terminal reaches of North Croker Bay Glacier, where the glacier is grounded below sea level (Fig. 6a). It is not, however, found along Belcher and Southeast 1 Glaciers which are also grounded below sea level.

Identification of distinct flow regimes across the ice cap indicates that the mode of ice movement evolves as one of a few possible sequences along a flowline between the interior region and the ice-cap margin. The initial transition occurs at the head of the outlet glaciers where cold-based ice moving by internal deformation only (Bentley, 1987) transforms to warm-based flow, and basal sliding commences. This mode of flow continues until the glacier either (a) reverts back to cold-based where flow is by internal deformation only, or (b) is enhanced by high driving stresses or narrowing bedrock valleys. Glaciers that transform into (b) likely experience high rates of internal deformation (Truffer and Echelmeyer, 2003) and enhanced basal sliding as a result of the penetration of surface meltwater through crevasses during the summer melt season (Zwally and others, 2002; Boon and Sharp, 2003; Copland and Sharp, 2003a). A third transition occurs near the termini of a few glaciers where $\tau_{d}$ is greatly reduced but high velocities are maintained. The mechanics of this mode of glacier flow are 

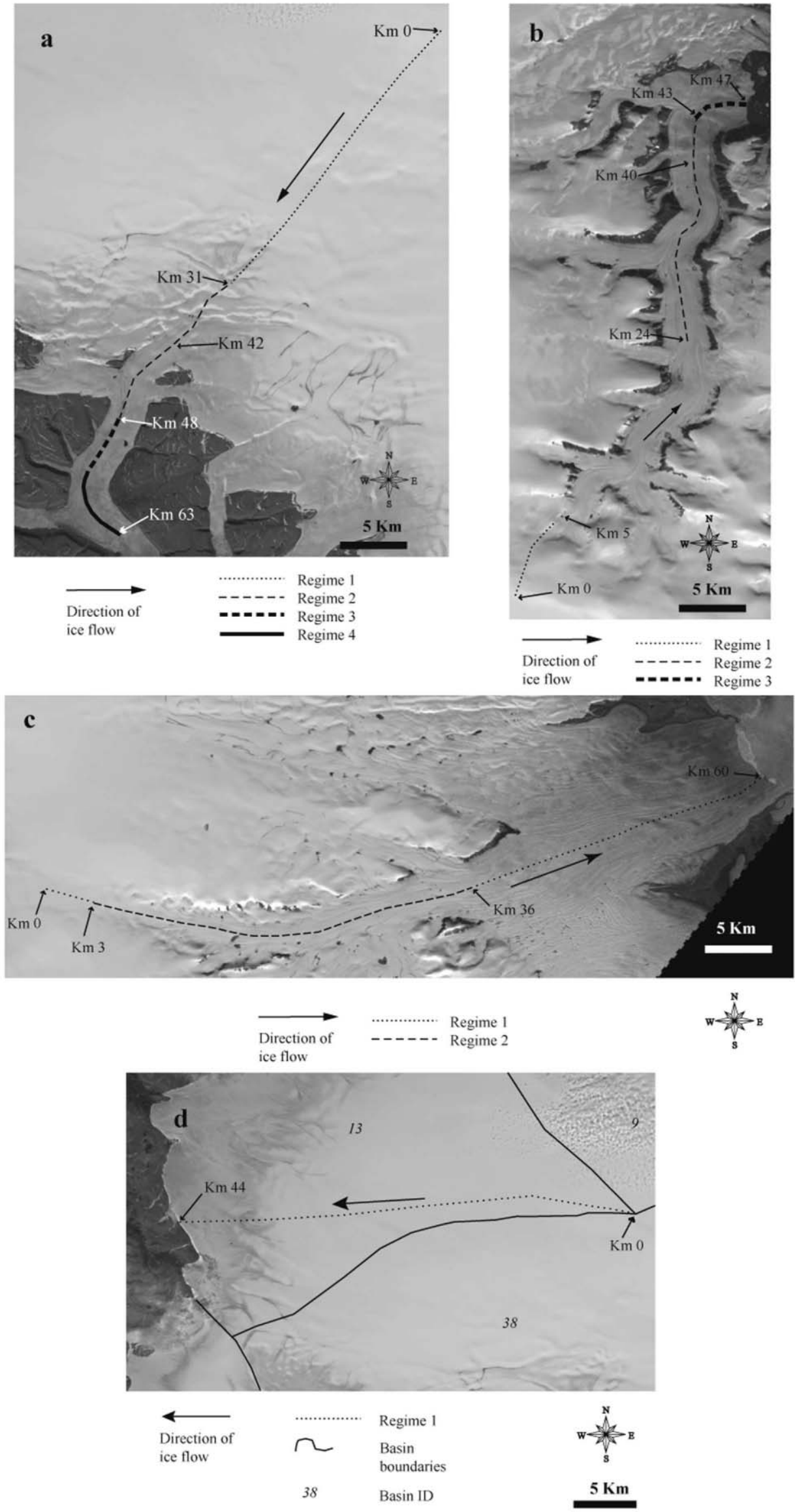

Fig. 5. Planimetric view of the dominant flow regimes along (a) North Croker Bay Glacier, (b) Belcher Glacier, (c) Southeast 1 Glacier and (d) the western lobe. Centre-line profiles are superimposed on a subset of the 1999 Landsat ETM+ satellite imagery. Locations of image subsets and profiles are identified in Figure 7. 

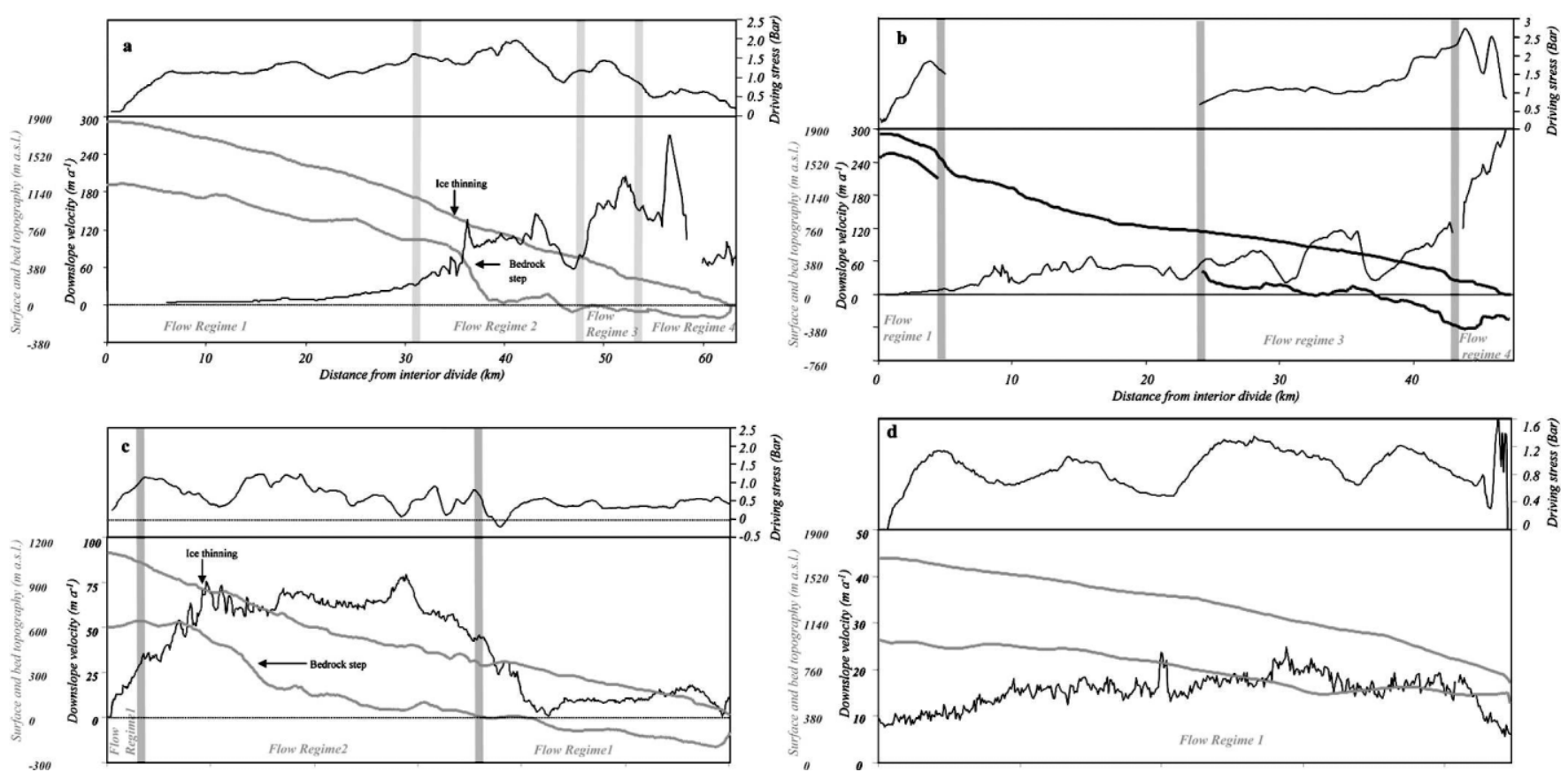

Fig. 6. Profiles of driving stress, surface and bed topography, and downslope velocity along (a) North Croker Bay Glacier, (b) Belcher Glacier, (c) Southeast 1 Glacier and (d) the western lobe. Gaps in the downslope velocity profile of (a) between km 0-5 and km 58-59 represent sections where InSAR data could not be derived. The absence of bed topography data in (b) between $\mathrm{km} 4$ and 24 precluded calculation of $\tau_{\mathrm{d}}$ throughout this zone.

likely similar to ice-stream flow where glacier movement occurs over a highly deformable and/or lubricated bed and the main resistive forces to flow occur at the glacier margins (Bentley, 1987; Truffer and Echelmeyer, 2003).

Threshold values of $v / h$ and $\tau_{\mathrm{d}}$ separating the four distinct flow regimes in the scatter plots were applied to raster datasets of these parameters in order to map the distribution of ice-flow regimes across the entire ice cap. For the raster grids, surface slope was averaged as a function of area rather than in an along-profile direction. This spatial averaging has the effect of slightly over- (under-) estimating the slope relative to the profile analyses over high (low) slope areas. These variations, however, had no effect on the flow regime classification.

Further uncertainties in $\tau_{\mathrm{d}}$ may derive from the fact that the glacier shape factors were not included in the computed values of $\tau_{\mathrm{d}}$. A few representative shape factor values were computed along the major outlet glaciers (assuming a parabolic glacier cross-section; Paterson, 1984) and indicated that applying this correction could reduce the computed values of $\tau_{\mathrm{d}}$ by up to $\sim 25 \%$. It is also possible that the longitudinal averaging used in this study (10h) was inadequate to fully remove the effects of longitudinal stress gradients from $\tau_{\mathrm{d}}$. In particular, near the glacier termini where averaging was $<10 \mathrm{~h}$, computed values of $\tau_{\mathrm{d}}$ may be slightly higher than the true values. In any case, slight discrepancies between the actual and computed values of $\tau_{\mathrm{d}}$ would have only minor implications for flow-regime classification relating exclusively to the separation of flow regime 3 from flow regime 4 .

Approximately $50 \%$ of the mapped area of the ice cap was classified as flow regime 1 which includes the interior region above $1000 \mathrm{~m}$ a.s.l. as well as $\sim 600 \mathrm{~km}^{2}$ of the southeast sector which lies below $300 \mathrm{~m}$ a.s.l. (Fig. 7). Flow regime 2 is confined mainly to the outlet glaciers, but it also occurs in some small areas along the western margin. Excluding the areas that were not mapped, this regime comprises approximately $22 \%$ of the total area east of the central divide (basins 3, 10, 11, 15, 20, 24, 25, 29, 30, 33, $35,36,37,40,39,60,66,70$ and 73 ) but only $8 \%$ of the area west of the central divide (basins 9, 13, 38, 43, 54, 61, 65 and 67), indicating that basal motion is much more prevalent in the east. Flow regime 3 occurs up to $22 \mathrm{~km}$ upglacier from the termini of North and South Croker Bay Glaciers and up to $25 \mathrm{~km}$ up-glacier from the terminus of Belcher Glacier (along Belcher tributary 2), reflecting the combination of relatively high driving stresses and high velocities in these regions. Flow regime 4 is confined to the termini of North Croker Bay, East 3, East Central 1 and South Cunningham Glaciers as well as a small section along Southeast 2 Glacier. The glaciers classified as flow regime 4 are all grounded above sea level except for the terminus region of North Croker Bay Glacier, suggesting that reduced basal friction of these glaciers may be attributed to the presence of deformable sediments at the bed rather than to buoyancy effects at tidewater margins.

\section{Rates of iceberg calving}

The rate of ice calved directly into the ocean due to flux at the tidewater margins was estimated to be $0.42 \pm 0.14 \mathrm{~km}^{3} \mathrm{a}^{-1}$. This equates to a calving flux rate of $16.8 \pm 5.7 \mathrm{~km}^{3}$ between 1960 and 1999, assuming invariant glacier flow velocities over this time interval. Volume loss due to retreat of the tidewater termini increases the total mass loss by $3.6 \pm 0.026 \mathrm{~km}^{3}$, resulting in a total volume loss due to iceberg calving of $20.5 \pm 4.7 \mathrm{~km}^{3}$ over the past 40 years. The northeast sector (basins 10, 11, 15, 20, 24, 25, 29, 30, 31, 33 and 36$)$ produced $67 \%$ of the total volume of ice calved. Belcher Glacier alone was responsible for $70 \%$ of this amount, which equates to almost half (47\%) of the ice-cap 


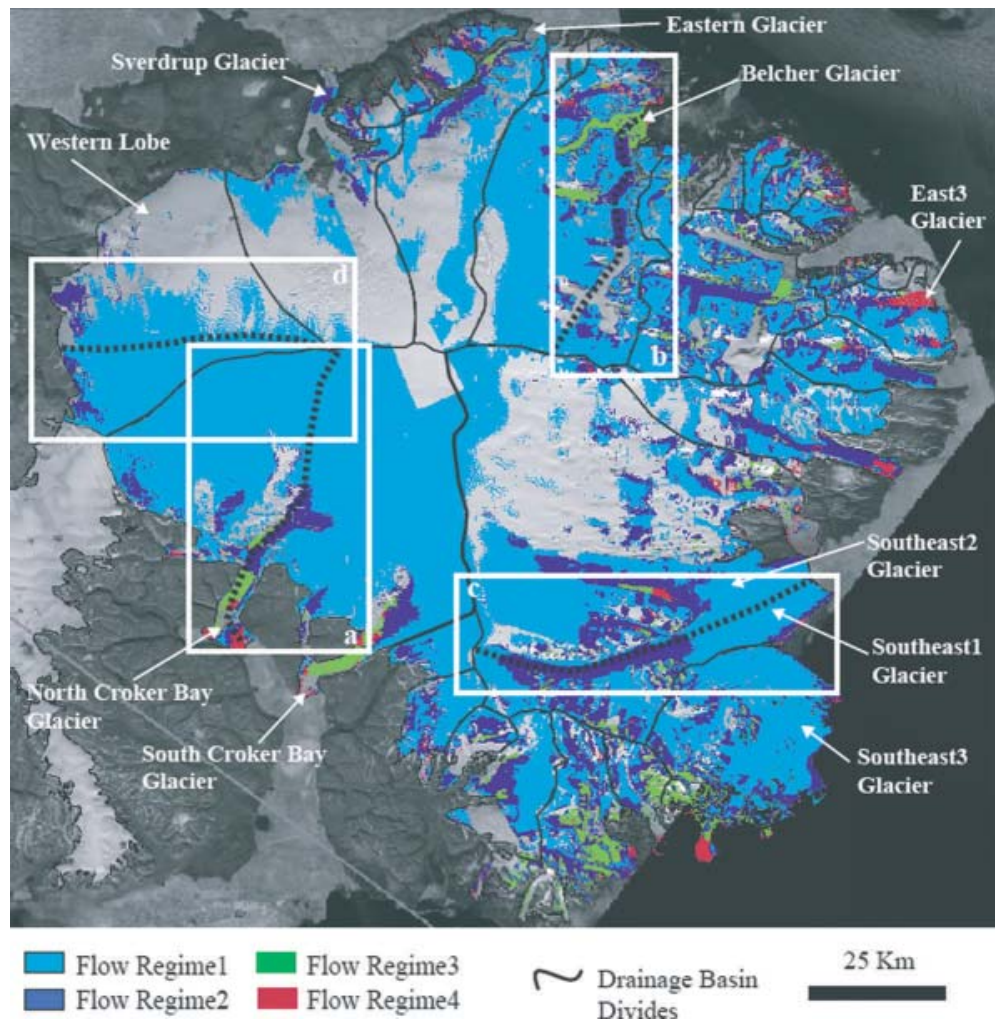

Fig. 7. Mapped distribution of classified flow regimes across Devon Ice Cap. White boxes indicate the location of image subsets and centreline profiles in Figure 5.

total (Fig. 8). Most of the mass lost from Belcher Glacier $(\sim 93 \%)$ is accounted for by ice flux as opposed to terminus change. This reflects the relatively thick ice $(\sim 250 \mathrm{~m})$ and high velocity (up to $290 \mathrm{~m} \mathrm{a}^{-1}$ ) at this ice front. Although two major glaciers terminating at the southeast margin of the ice cap (basins 39 and 60) have extensive calving fronts ( 18 km long), this region accounts for only $16 \%$ of the total calving flux. This is due mainly to the low surface velocities of these glaciers. The southernmost calving front (basin 60) is unique in that the majority of mass calved from this terminus is due to retreat of the ice front $(\sim 60 \%)$ rather than ice flux. North and South Croker Bay Glaciers have advanced since 1960. This reduces the calculated volume loss due to flux by $12 \%$. Similarly, glacier advance reduced the calculated calving flux of Sverdrup Glacier by $13 \%$. Mass loss due to calving from the western glaciers accounts for $\sim 10 \%$ of the total volume of ice calved from Devon Ice Cap. In total, the eight major tidewater glaciers draining the ice cap (indicated in Fig. 8 ) are responsible for $\sim 90 \%$ of the total discharge of ice calved. The rest is derived from small alpine glaciers (generally $<1 \mathrm{~km}$ wide) that flow from basins in the northeast and eastern sectors.

\section{CONCLUSIONS}

The continuous surface velocity field of Devon Ice Cap mapped using InSAR techniques reveals a significant contrast in ice-flow dynamics between the east and west sides of the ice cap. The eastern half of the ice cap is drained by several fast-flowing outlet glaciers that extend up to $60 \mathrm{~km}$ inland from the ice-cap margin, and in some cases reach within a few kilometres of the central ice divides. The western half of the ice cap is drained primarily by sheet flow, but also by a few outlet glaciers that are restricted to within $<30 \mathrm{~km}$ of the ice-cap margins.

The predominant ice-flow regimes were classified based on the relationship between the ratio of surface velocity to ice thickness and the driving stress derived along four flowlines from distinctly different regions across the ice cap. The classified regimes were mapped across $\sim 75 \%$ of the icecap surface for which both surface velocity and icethickness data are available. The interior and southeast ice regions were classified as flow regime 1 type flow and are characterized by frozen bed conditions where ice movement is by internal deformation alone. The main sections of most outlet glaciers were classified as flow regime 2, in which basal motion occurs. The transition to flow regime 2 along a flowline marks the onset of basal sliding and is usually associated with ice flow over a step in the bedrock topography. The appearance of flow stripes on the ice surface in regions of flow regime 2 supports the argument that basal motion makes a major contribution to the surface velocity in these regions. Flow regime 3 is characterized by enhanced basal motion and internal deformation due to a significant increase in driving stress. Flow regime 4 is characterized by a wide range in values of $v / h$ (including maximum values) within sections of the glacier with consistently low values of driving stress. This flow regime occurs within a few kilometres of the termini and is indicative of minimal basal friction that may result from the presence of deformable sediments at the glacier bed.

Approximately $20.5 \mathrm{~km}^{3}$ of ice was calved from Devon Ice Cap between 1960 and 1999. Approximately 89\% of the total volume of ice calved was discharged from the eastern margin, with the largest single source being Belcher Glacier which was responsible for $\sim 50 \%$ of the total amount. 


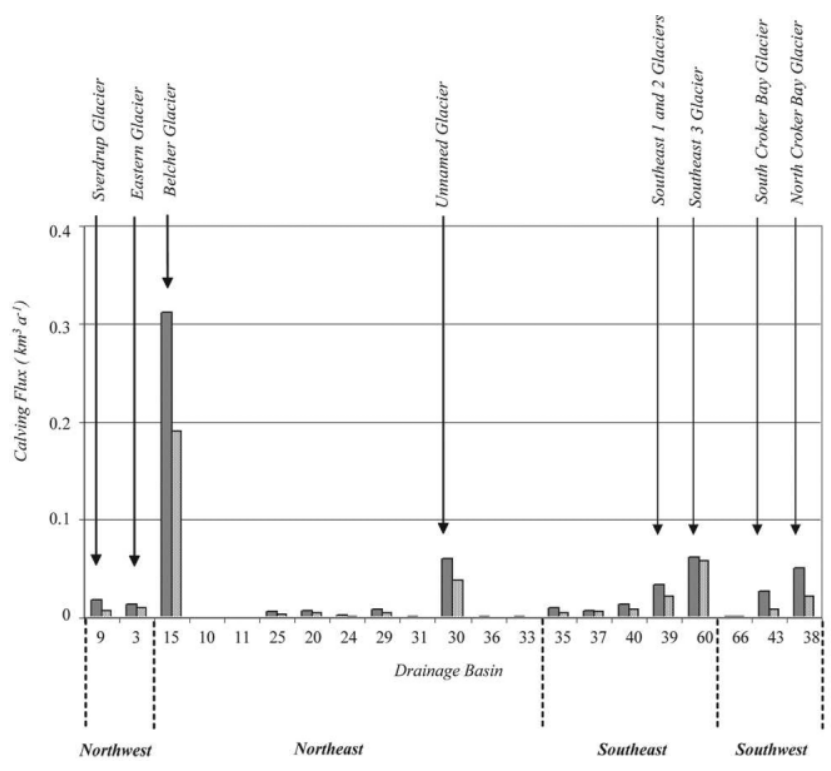

Fig. 8. Distribution of iceberg calving rates on Devon Ice Cap. Solid bars represent the upper calving flux estimate, and the shaded bars represent the lower calving flux estimate.

Comparing the total volume of ice lost due to calving and total mass loss of $\sim 67 \mathrm{~km}^{3}$ from Devon Ice Cap between 1960 and 1999 (Burgess and Sharp, 2004) indicates that iceberg calving may account for up to $30 \%$ of the total volume loss over the past 40 years. Iceberg calving therefore represents a significant form of ablation from Devon Ice Cap and should be accounted for when determining the state of health of this ice mass as a whole. Dowdeswell and others (2002) also found that about $40 \%$ of mass loss from the $5575 \mathrm{~km}^{2}$ Akademii Nauk ice cap, Severnaya Zemlya, Russia, was lost by iceberg calving. Together with the evidence from Devon Ice Cap, this suggests that iceberg production is an important component of the total mass loss from large Arctic ice caps.

\section{ACKNOWLEDGEMENTS}

This work was supported by grants from the Natural Sciences and Engineering Research Council (NSERC), Canada, and the Meteorological Service of Canada (CRYSYS program) to M. Sharp. D. Burgess received an IPS-2 scholarship from NSERC and Land Data Technologies Inc., and grants from the Canadian Circumpolar Institute and Northern Scientific Training Program (Department of Indian and Northern Affairs Canada), and D. Mair was supported by a Research Fellowship from the Leverhulme Trust. We also acknowledge Innovation and Science Research Investments Program (ISRIP) for a grant to purchase a DGPS, and NASA/Alaska Satellite Facility (ASF) for providing the ERS-1/-2 radar imagery. Logistical support in the field was provided by the Polar Continental Shelf Project, Natural Resources Canada (contribution No. 628-00). UK funding for the acquisition, analysis and interpretation of airborne radio-echo sounding data was provided by Natural Environment Research Council grant GR3/12469 and the European Union SPICE (Software Process Improvement and Capability dEtermination) project. Finally, we thank L. Gray and N. Short (Canada Centre for Remote Sensing) for software training and access to the speckle-tracking programs.

\section{REFERENCES}

Alt, B.T. 1978. Synoptic climate controls of mass-balance variations on Devon Island Ice Cap. Arct. Alp. Res., 10(1), 61-80.

Bentley, C.R. 1987. Antarctic ice streams: a review. J. Geophys. Res., 92(B9), 8843-8858.

Bingham, R.G., P.W. Nienow and M.J. Sharp. 2003. Intra-annual and intra-seasonal flow dynamics of a High Arctic polythermal valley glacier. Ann. Glaciol., 37, 181-188.

Boon, S. and M. Sharp. 2003. The role of hydrologically-driven ice fracture in drainage system evolution on an Arctic glacier. Geophys. Res. Lett., 30(18). (10.1029/2003GL018034.)

Budd, W.F. and I.N. Smith. 1981. The growth and retreat of ice sheets in response to orbital radiation changes. International Association of Hytdological Sciences Publication 131 (Symposium at Canberra 1979 - Sea Level, Ice and Climatic Change), 369-409.

Burgess, D.O. and M.J. Sharp. 2004. Recent changes in areal extent of the Devon ice cap, Nunavut, Canada. Arct. Antarct. Alp. Res., 36(2), 261-271.

Cooper, A.P.R., N.F. Mclntyre and G. de Q. Robin. 1982. Driving stresses in the Antarctic ice sheet. Ann. Glaciol., 3, 59-64.

Copland, L. and M. Sharp. 2001. Mapping thermal and hydrological conditions beneath a polythermal glacier with radioecho sounding. J. Glaciol., 47(157), 232-242.

Copland, L., M.J. Sharp and J.A. Dowdeswell. 2003a. The distribution and flow characteristics of surge-type glaciers in the Canadian High Arctic. Ann. Glaciol., 36, 73-81.

Copland, L., M.J. Sharp, P.W. Nienow and R.G. Bingham. 2003b. The distribution of basal motion beneath a High Arctic polythermal glacier. J. Glaciol., 49(166), 407-414.

Cress, P. and R. Wyness. 1961. Observations of glacial movements. Arctic, 14(4), 257-259.

Cumming, I. and J. Zhang. 2000. Measuring the 3-D flow of the Lowell Glacier with InSAR. In Fringe '99: Second ESA International Workshop on ERS SAR Interferometry, Liège, Belgium, 10-12 November 1999. European Space Agency, 1-9.

Dowdeswell, J.A. and M. Williams. 1997. Surge-type glaciers in the Russian High Arctic identified from digital satellite imagery. J. Glaciol., 43(145), 489-494.

Dowdeswell, J.A. and 10 others. 2002. Form and flow of the Academy of Sciences ice cap, Severnaya Zemlya, Russian High Arctic. J. Geophys. Res., 107(B4). (10.1029/2000JB000129.)

Dowdeswell, J.A., T.J. Benham, M.R. Gorman, D. Burgess and M. Sharp. 2004. Form and flow of the Devon Island ice cap, Canadian Arctic. J. Geophys. Res., 109(F02002). (10.1029/ 2003JF000095.)

Gabriel, A.K., R.M. Goldstein and H.A. Zebker. 1989. Mapping small elevation changes over large areas: differential radar interferometry. J. Geophys. Res., 94(B7), 9183-9191.

Gray, L., N. Short, K.E. Mattar and K.C. Jezek. 2001. Velocities and flux of the Filchner Ice Shelf and its tributaries determined from speckle tracking interferometry. Can. J. Remote Sensing, 27(3), 193-206.

Gudmundsson, G.H., C.F. Raymond and R. Bindschadler. 1998. The origin and longevity of flow stripes on Antarctic ice streams. Ann. Glaciol., 27, 145-152.

Gudmundsson, G.H., G. Adalgeirsdóttir and H. Björnsson. 2003. Observational verification of predicted increase in bedrock-tosurface amplitude transfer during a glacier surge. Ann. Glaciol., 36, 91-96.

Iken, A. 1972. Measurements of water pressure in moulins as part of a movement study of the White Glacier, Axel Heiberg Island, Northwest Territories, Canada. J. Glaciol., 11(61), 53-58.

Joughin, I. 2002. Ice-sheet velocity mapping: a combined interferometric and speckle-tracking approach. Ann. Glaciol., 34, 195-201.

Joughin, I., R. Kwok and M. Fahnestock. 1996. Estimation of icesheet motion using satellite radar interferometry: method and error analysis with application to Humboldt Glacier, Greenland. J. Glaciol., 42(142), 564-575. 
Koerner, R.M. 1970. The mass balance of the Devon Island ice cap, Northwest Territories, Canada, 1961-66. J. Glaciol., 9(57), 325-336.

Mair, D.W.F., D.O. Burgess and M.J. Sharp. 2004. Thirtyseven year mass balance of the Devon Ice Cap, Nunavut, Canada determined by shallow ice coring and melt modelling. J. Geophys Res. 110(F01011). (doi: 10.1029/ 2003JF000099.)

Massonnet, D. and K.L. Feigl. 1998. Radar interferometry and its application to changes in the Earth's surface. Rev. Geophys., 36(4), 441-500.

Mclntyre, N.F. 1985. The dynamics of ice-sheet outlets. J. Glaciol., 31(108), 99-107.

Paterson, W.S.B. 1994. The physics of glaciers. Third edition. Oxford, etc., Elsevier.

Truffer, M. and K.A. Echelmeyer. 2003. Of isbræ and ice streams. Ann. Glaciol., 36, 66-72.
Unwin, B.V. 1998. Arctic ice cap velocity variations revealed using ERS SAR interferometry. (PhD thesis, University College London.) Vachon, P.W., D. Geudtner, K. Mattar, A.L. Gray, M. Brugman and I. Cumming. 1996. Differential SAR interferometry measurements of Athabasca and Saskatchewan glacier flow rate. Can. J. Remote Sensing, 22(3), 287-296.

Webb, F.H. and J.F. Zumberge. 1995. An introduction to GIPSY/ OASIS-II. Pasadena, CA, California Institute of Technology. US National Aeronautics and Space Administration. Jet Propulsion Laboratory.

Zebker, H.A., P.A. Rosen, R.M. Goldstein, A. Gabriel and C.L. Werner. 1994. On the derivation of coseismic displacement fields using differential radar interferometry: the Landers earthquake. J. Geophys. Res., 99(B10), 19,617-19,634.

Zwally, H.J., W. Abdalati, T. Herring, K. Larson, J. Saba and K. Steffen. 2002. Surface melt-induced acceleration of Greenland ice-sheet flow. Science, 297(5579), 218-222.

MS received 21 July 2004 and accepted in revised form 30 January 2005 